\title{
Designing project schedule using crashing method to compress the fiber to the home project schedule
}

\author{
Zha Sha Putri Anugerah*, Devi Pratami, Mohammad Deni Akbar \\ School of Industrial and System Engineering, Telkom University, Bandung, Indonesia \\ zhashaputri@gmail.com; pratami.devi@gmail.com; denimath@telkomuniversity.ac.id \\ *Corresponding Authors: zhashaputri@gmail.com
}

\section{ARTICLE INFO}

\section{Keywords}

Project Scheduling;

Acceleration Schedule; Crashing;

Time-Cost Trade-Off; Adding Overtime Hours;

Increasing Number of

Workers.

\section{Article history}

Received:

November 1, 2020

Revised:

January 13, 2021

Accepted:

January 21, 2021

Available online:

February 24, 2021

\section{ABSTRACT}

$A B C$ Company is an agent of network construction, operation, and maintenance. ABC Company is currently implementing the STTF (Shit to the Front) project, which is the project to add FTTH (Fiber to the Home) networks in areas that can have high customer demand. One of the STTF project construction sites is the Indra Prahasta II housing location. However, the project is currently experiencing work delays due to the Covid-19 disaster in Indonesia. Delays in project execution can result in potential prospects choosing another company that provides similar services. The project schedule can be accelerated using the crashing method and TCTO (Time Cost Trade-Off) analysis to solve this problem. This research's acceleration will be carried out with alternatives for adding 3 hours, 2 hours, 1 hour, and an alternative to increasing workers' number. This project has an average duration of 55 working days with a total cost of $R p$ $604,124,460$. The results obtained from data processing, on the alternative of adding 1 hour of overtime work, the total duration becomes 54 working days with total project cost is Rp $605,734,138$. In addition to 2 hours of overtime work, the project's total duration can be reduced to 54 days with a total project cost $\mathrm{Rp} 606,803,619$. And for the addition of 3 hours overtime, the total duration can be shortened to 54 days with a total cost of $R p$ $606,803,619$. As for increasing the number of workers, project work duration can be shortened to 54 working days with a total project cost Rp 604,556,748.

\section{Introduction}

A project is an activity whose implementation time is limited. Project activities are temporary activities, where before the project is implemented, usually the beginning and end of its implementation time has been determined (PMI, 2017). The project has a time limit that must be considered means the project must be completed before or on time that has been determined. However, the actual projects often experience delays. Project conditions in the field usually cause delays that often occur in projects, method selection errors, design changes, weather effects, insufficient workforce needs, and deficiencies or defects in materials and equipment (Armalisa et al., 2011), while according to Kusumadarma et al. (2020). Delays in a project are divided into three parts: Excusable NonCompensable Delays, Excusable Compensable Delays, and non-excusable Delays.

ABC Company is an agent for developing, operating, and maintaining access networks, especially fiber optic access networks. At this time, ABC Company is currently working on many projects that 
must be completed, including the STTF (Shift to The Front) project. The STTF project is a project to add FTTH (Fiber to The Home) network in areas with high customer demand, such as new housing, new apartments, and new malls. In 2020, the STTF project entered the second batch in its implementation. One of the second batch locations of STTF projects is at the Indra Prahasta 2 housing complex located in Kopo. Indra Prahasta 2 is a new housing complex that is considered to have high demand as potential customers.

The second batch STTF project for the Indra Prahasta 2 housing location consists of 9 activities with 55 working days. Project work is carried out by partners who usually have often collaborated with ABC Company. However, currently, the second batch of the STTF project for the Indra Prahasta 2 housing location is experiencing work delays due to Indonesia's Covid-19 disaster. Due to project delays, the company's partner ABC Company cannot work on the FTTH development project to meet prospective customers' needs in Indra Prahasta 2 housing. Unfulfilled needs of prospective customers can cause potential customers to choose other companies that provide similar services. Based on the history of similar projects, several obstacles can cause delays in project work. Several factors cause the delays that occurred. Following are the factors that cause delays in the project shown in the fishbone diagram.

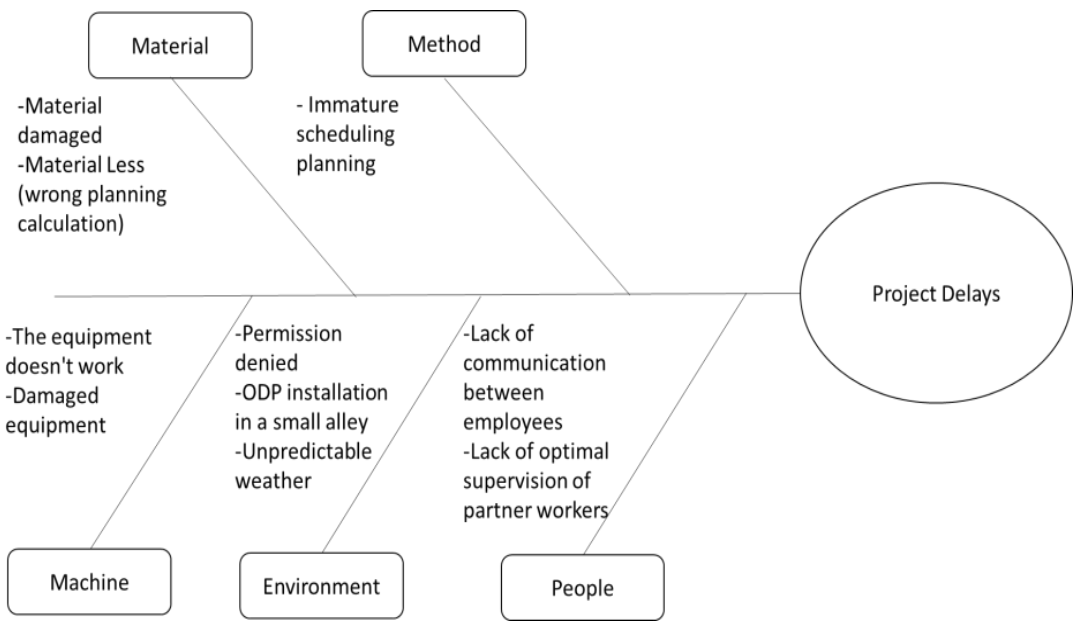

Figure 1. Fishbone Diagram Project Delays

Based on Figure 1, it can be seen that there are factors that affect late project work. These factors consist of material, machine, environmental, human, and method factors. Based on similar project history, the leading cause of project delays is due to the licensing process that was too long. The documents that must be completed and do the permits for local community organizations take a long time to get approval to build an FTTH network in that location (Pratami et al., 2018).

The recapitulation of similar projects based on ABC Company's development monitoring spreadsheet is useful for monitoring the latest project progress. It can be seen from the five existing projects that are in the licensing process. The licensing process is waiting for confirmation from related parties, waiting for socialization, and waiting for data on customers interested in using internet services. Therefore, so that the project does not exceed the predetermined deadline and speed up the project's time to meet prospective customers' needs, a new scheduling plan is needed to accelerate the project duration. 
The making of new scheduling plans to speed up the project is needed so that the project does not exceed the predetermined deadline and speed up the project work time to meet prospective customers' needs (Pratami et al., 2018). Planning in a project is something that needs to be appropriately considered. Making accelerated new scheduling should not be done haphazardly. Accelerating time will increase project implementation costs. The additional costs to be incurred are as minimal as possible and still pay attention to project work standards. In accelerating the schedule, it can be done by adding work hours, tools, number of workers, and using the right construction method (Nicholas, 2012).

The selection of the right method can affect the project's duration, and this is because if the method used is not suitable, the project can result in delays. One of the efforts to speed up the schedule is by using the crashing method. The crashing method is a method to speed up project time by reducing the time from various important project activities to less than the average time that has been determined when planning (Nicholas, 2012). According to PMI (2017), the crashing method is a technique used to shorten schedule duration, but additional cost is added.

In this study, the alternative addition was chosen to speed up the project's duration by adding overtime working hours and additional workers with Time-Cost Trade-Off (TCTO) analysis. By adding overtime hours and adding workers, this research proposes in optimizing the project time with the minimum cost increase in the project to accelerate the completion of the second batch STTF project for Indra Prahasta 2 housing location.

\section{Literature Review|}

\subsection{Plan Schedule Management}

Plan schedule management establishes policies, procedures, and documentation to plan, develop, manage, implement, and control project schedules. The plan schedule management process's main benefit is to provide guidance and direction on how the project schedule will be managed across the project (PMI, 2017) as we have known that the STTF project for the Indra Prahasta 2 housing location is experiencing work delays due to the Covid-19 disaster in Indonesia. Due to project delays, the company's partner ABC Company cannot work on the FTTH development project to meet prospective customers' needs in Indra Prahasta 2 housing.

\subsection{Critical Path Method}

According to PMI (2017), the Critical Path Method or CPM is a method used to estimate the minimum project duration and to determine flexibility in the scheduling network. Then, according to Nicholas (2012), CPM is also known as critical path analysis, an analysis of project networks used to estimate the total duration or lifespan of a project. A critical path is a set of activities located on the network diagram's longest route and has minimal slack and float values. Slack and float are the amount of time delay activity (allowance time) without delaying or interrupting the entire project's completion.

\subsection{Crashing method}

The crashing method is a technique used to speed up project time by reducing the time from various project activities on the critical path to less than the average time determined when planning (PMI, 2017). The crashing method aims to optimize work time by shortening work duration with the lowest 
additional cost. The crashing method only affects activities on a critical path, where other resources will help shorten the activity duration.

\subsection{Time-Cost Trade-Off}

Time cost trade-off (TCTO) is a schedule compression technique to get more profitable projects in terms of time, cost, and revenue. The aim is to identify projects with a duration that can be accelerated and minimize its total cost. Reducing the project duration is done by selecting certain activities that are on the critical path. Next, do the compression starting from the critical path, which has the lowest cost slope value (Setiawan et al, 2012). In this study, the TCTO method is used to determine the comparison of the two alternative accelerations chosen, namely the addition of working hours and additional workers following the Decree of the Minister of Manpower and Transmigration Number KEP.102 / MEN / VI / 2004 and Regulation of the Minister of Public Works of the Republic of Indonesia Number: 11 / PRT / M / 2013 concerning Guidelines for Analysis of Unit Prices for Public Works.

\section{Research Methodology}

Figure 2 presents the research methodology. The preliminary stage starts from looking for literature studies by reading journals related to research methods. The preliminary stage is the stage for determining an overview of the problem and the research objectives carried out on the project. Data will be searched and collected at the data collection stage that will support this research's work. Data collection is carried out to perform project data processing so that the data can be calculated and produce the required information. There are two types of data needed in the study at the data collection stage, namely primary and secondary data. 


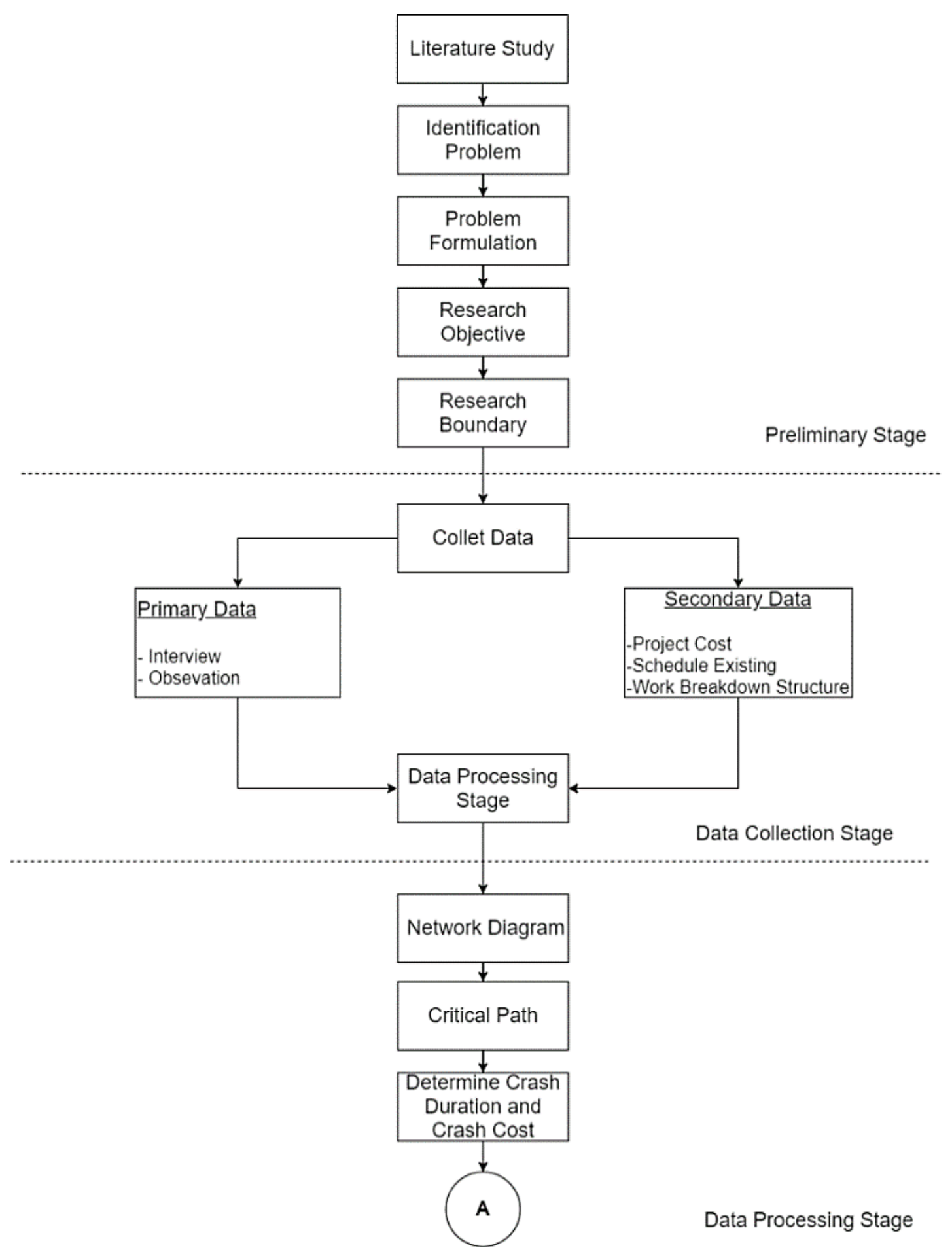

Figure 2. Methodology Step 1 


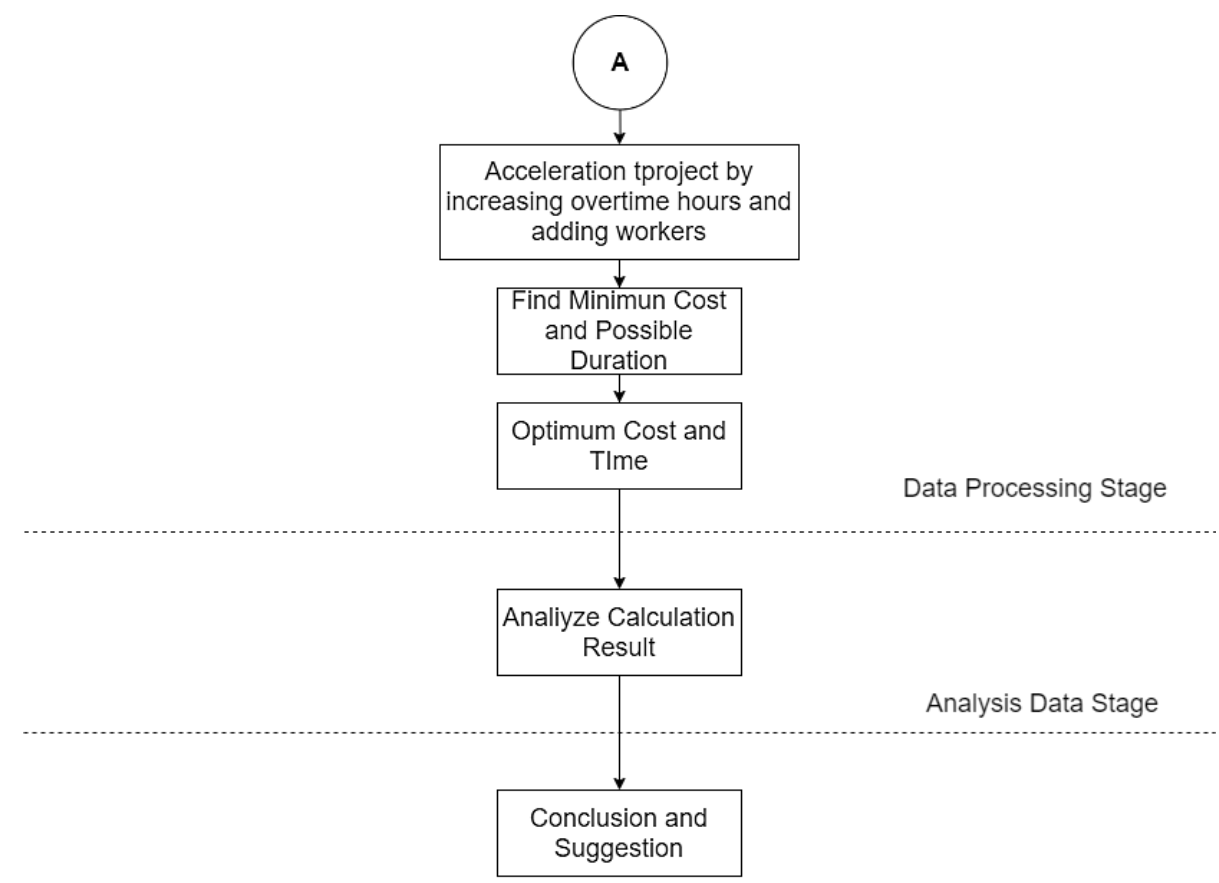

Conclusion and Sugestion on Stage

Figure 3. Methodology Step 2

The processing stage can be carried out after the data collection process is complete. At the data processing stage, work activities were compiled at STTF batch two for Indra Prahasta 2 housing locations with a network diagram. A network diagram is a project visualization based on network planning. The network diagram contains a network with activity trajectories and the sequence of events that occur during project implementation (Nicholas, 2012). The results obtained will show the critical path, which in the next stage, activities on the critical path will be accelerated. After successfully determining the activities that are on the critical path, the crash duration and crash cost calculations are performed to determine the cost slope. Time-Cost Trade-Off (TCTO) analysis is employed to determine which cost is the most optimum from schedule acceleration. TCTO is a schedule compression technique for getting more profitable projects in terms of time, cost, and revenue. The aim is to identify projects with accelerated duration and minimize the total cost of the project. After completing the schedule compression stage, the minimum results can be determined by calculating the time efficiency and cost value of the STTF batch two for the Indra Prahasta II housing location.

The data analysis stage was carried out by analyzing the results of data processing. The data analysis carried out aims to provide detailed information on the results of data processing to suit the research objectives and answer the problem formulation. At this stage of data analysis, an analysis of the project's planned schedule and cost acceleration will be carried out. In the conclusions and suggestions stage, detailed conclusions will be made following the research objectives. They can answer the problem formulations that have been compiled in the acceleration of the STTF batch two Indra Prahasta housing locations 2. Suggestions are addressed to the project team or further research related to similar projects used as material evaluation on project acceleration planning. 


\section{Results and Discussion}

\subsection{Alternative Acceleration}

The Normal working time is 8 hours/day. Work time starts at $08.00-12.00$, breaks from $12.00-13.00$, and continues from $1 \mathrm{pm}-5 \mathrm{pm}$. Based on the Decree of the Minister of Manpower and Transmigration of the Republic of Indonesia Number KEP.102 / MEN / VI / 2004 concerning Overtime Work and Overtime Wages, the maximum overtime working time day is 3 hours. Based on the Decree of the Minister of Manpower and Transmigration of the Republic of Indonesia Number KEP.102/MEN/Vl/2004 concerning Overtime Work and Overtime Wages, overtime pay is calculated as 1.5 times the regular wage for the first hour and the following working hours is two times average wages. The productivity of workers during overtime is calculated according to the decrease in productivity as shown in Table 1 . The decline in productivity is caused by worker fatigue, limited vision at night, and cold weather conditions.

Table 1. Productivity Decline Coefficient

\begin{tabular}{|c|c|c|c|}
\hline $\begin{array}{c}\text { Overtime } \\
\text { Hours }\end{array}$ & $\begin{array}{c}\text { Productivity } \\
\text { Index Decrease }\end{array}$ & $\begin{array}{c}\text { The decrease in } \\
\text { Job Performance }\end{array}$ & $\begin{array}{c}\text { Presentation of Decreased } \\
\text { Job Performance (\%) }\end{array}$ \\
\hline $\mathrm{A}$ & $\mathrm{B}$ & $\mathrm{C}=\mathrm{AxB}$ & $\mathrm{E}=100 \%-\mathrm{C}$ \\
\hline 1 & 0.1 & 0.1 & $90 \%$ \\
\hline 2 & 0.1 & 0.2 & $80 \%$ \\
\hline 3 & 0.1 & 0.3 & $70 \%$ \\
\hline
\end{tabular}

The addition of workers is done as much as $25 \%$ of the standard index of labor requirements per day. The standard index is set based on the coefficient value in the Regulation of the Minister of Public Works of the Republic of Indonesia Number: 11 / PRT / M / 2013 concerning Guidelines for Analysis of Unit Prices for Public Works. The addition of workers is carried out in critical activities and only in excavation work, installation work and pipe installation work, and accessories (see Table 2).

Table 2. Number of Workers

\begin{tabular}{|c|l|c|c|}
\hline Code & \multicolumn{1}{|c|}{ Activity } & Worker & Number of Worker \\
\hline H & Excavation & Excavation & 5 \\
\hline G & $\begin{array}{l}\text { Galvanized pipe installation, DHPE pipe, } \\
\text { and HDPE pipe fitting clamps and their } \\
\text { accessories }\end{array}$ & $\begin{array}{l}\text { Pipe } \\
\text { installation and } \\
\text { accessories }\end{array}$ & \\
\cline { 1 - 2 } I & Installation ODP 8 core & Installation & \\
\cline { 1 - 2 } & $\begin{array}{l}\text { Installation of cable duct fiber optic single } \\
\text { mode 12 core }\end{array}$ & \\
\cline { 1 - 2 } K & $\begin{array}{l}\text { Installation cable optic single-mode 12 } \\
\text { core }\end{array}$ & \\
\cline { 1 - 2 } L & Installation passive splitter 1:8 & \\
\hline
\end{tabular}




\subsection{Critical Path}

To perform crashing calculations, first, the critical path identification needs to be determined. The critical path is the path that has the most prolonged duration in completing project activities. In developing a critical pathway, it is necessary to know each activity's average duration and determine the relationship between activities. In the STTF project for Indra Prahasta 2 Housing locations, the critical path determination was carried out using the CPM method. From the processing results, 13 activities are on a critical path.

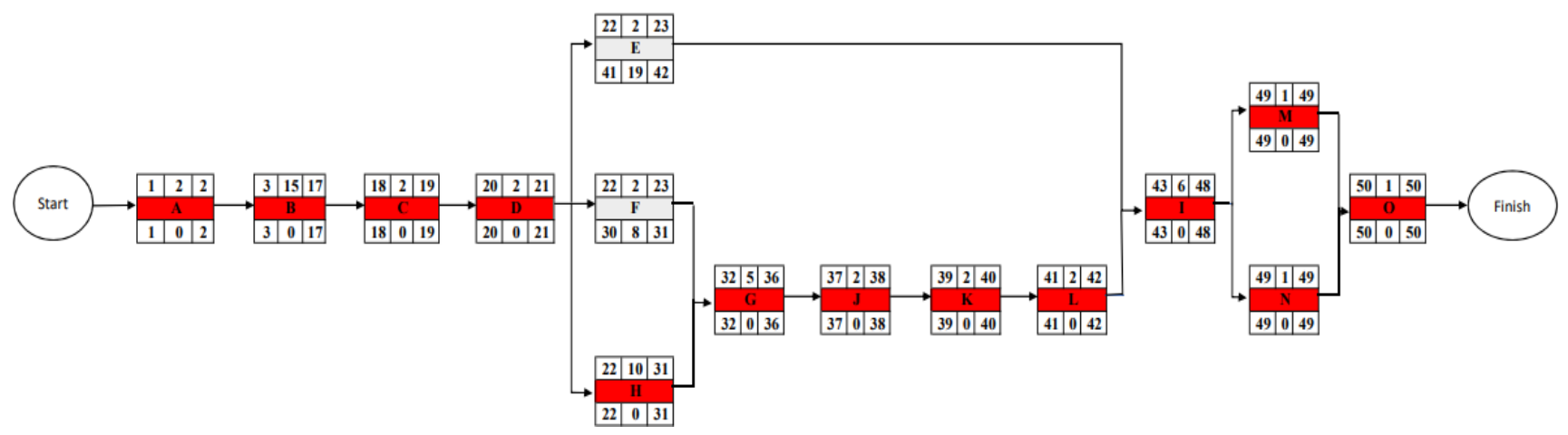

Figure 4. Network Diagram

\subsection{Alternative Working Overtime}

\subsubsection{Additional 1 Hour}

Table 3 is the result of schedule compression using the TCTO method. Inactivity B or compression stage 1 , the project's duration is accelerated from 15 days to 14 days so that the total duration of the project is 54 days. This acceleration in duration increased the direct costs of $R p 145,312$, so the total direct costs became Rp 539,542,152. The indirect cost at the compression stage 1 becomes Rp. $67,996,785$. And for the total project cost to Rp $607,211,937$. And inactivity $\mathrm{H}$ or compression stage 2, the project's duration is accelerated from 10 days to 9 days so that the project's total duration is 54 days. This acceleration in duration increased the direct costs of Rp 145,312, so the total direct costs became Rp 539,542,152. The indirect cost for compression stage 2 becomes Rp. 66,689,064. And for the total project cost to $\mathrm{Rp} 606,231,215$. Based on the calculation results, compression stage 2 has the minimum total cost value of $\mathrm{Rp} 606,231,215$ with a total project duration of 54 days.

Table 3. Additional 1 Hour

\begin{tabular}{|c|c|c|c|c|c|c|c|c|}
\hline \multirow[b]{2}{*}{ Code } & \multirow[b]{2}{*}{ Crash Activity } & \multirow{2}{*}{$\begin{array}{c}\text { Compression } \\
\text { stage }\end{array}$} & \multicolumn{2}{|c|}{ Duration } & \multirow{2}{*}{$\begin{array}{c}\text { Total } \\
\text { Duration }\end{array}$} & \multirow{2}{*}{$\begin{array}{l}\text { Direct Cost } \\
\text { (Rp) }\end{array}$} & \multirow{2}{*}{$\begin{array}{c}\text { Indirect Cost } \\
\text { (Rp) }\end{array}$} & \multirow[b]{2}{*}{ Total Cost (Rp) } \\
\hline & & & Normal & Crash & & & & \\
\hline & & Normal Stage & & & 55 & $539,396,839$ & \begin{tabular}{|l|}
$64,727,621$ \\
\end{tabular} & $604,124,460$ \\
\hline B & $\begin{array}{c}\mathrm{DRM} \text { and } \\
\text { licensing location }\end{array}$ & Stage 1 & 15 & 13 & 53 & $539,829,652$ & $67,669,785$ & $607,499,437$ \\
\hline $\mathrm{H}$ & $\begin{array}{c}\text { Earth Excavation } \\
\text { Works }\end{array}$ & Stage 2 & 10 & 9 & 54 & $539,829,652$ & $66,689,064$ & $606,518,715$ \\
\hline
\end{tabular}




\subsubsection{Additional 2 Hours}

Table 4 is the result of schedule compression using the TCTO method. Inactivity B or compression stage 1 , the project's duration was accelerated from 15 days to 13 days, so that the total duration of the project was 53 days. This acceleration in duration resulted in an additional direct cost of Rp 432,812, so the total direct cost becomes Rp 539,829,652. The indirect cost at the compression stage 1 becomes Rp. $67,669,785$. And for the total project cost to Rp 607,499,437. Then in activity $\mathrm{H}$ or compression stage 2, the project's duration is accelerated from 10 days to 9 days so that the project's total duration is 54 days. This acceleration in duration resulted in an additional direct cost of Rp. 432,812, so the total direct cost becomes Rp 539,829,652. The indirect cost for compression stage 2 becomes Rp $66,689,064$ and for the total project cost to Rp. 606,518,715.

In the activity I or compression stage 3, the project's duration is accelerated from 6 days to 5 days so that the project's total duration is 54 days. This acceleration in duration resulted in an additional direct cost of Rp. 432,812, so the total direct cost becomes Rp 539,829,652. The indirect cost for compression stage 3 becomes Rp 66,905,487. And for the total project cost to Rp 605,734,138. Based on the calculation results, the activity with the minimum total cost value is the activity I or compression stage 3 , which is $\mathrm{Rp} 605,734,138$ with a total project duration of 54 days.

Table 4. Additional 2 Hours

\begin{tabular}{|c|c|c|c|c|c|c|c|c|}
\hline \multirow{2}{*}{ Code } & \multirow{2}{*}{ Crash Activity } & \multirow{2}{*}{$\begin{array}{c}\text { Compression } \\
\text { stage }\end{array}$} & \multicolumn{2}{|c|}{ Duration } & \multirow{2}{*}{$\begin{array}{c}\text { Total } \\
\text { Duration }\end{array}$} & \multirow{2}{*}{$\begin{array}{l}\text { Direct Cost } \\
\text { (Rp) }\end{array}$} & \multirow{2}{*}{$\begin{array}{l}\text { Indirect Cost } \\
\text { (Rp) }\end{array}$} & \multirow{2}{*}{$\begin{array}{l}\text { Total Cost } \\
\text { (Rp) }\end{array}$} \\
\hline & & & Normal & Crash & & & & \\
\hline & & Normal Stage & & & 55 & $539,396,839$ & $64,727,621$ & $604,124,460$ \\
\hline B & \begin{tabular}{c|} 
DRM and \\
licensing location
\end{tabular} & Stage 1 & 15 & 13 & 53 & $539,829,652$ & $67,669,785$ & $607,499,437$ \\
\hline $\mathrm{H}$ & $\begin{array}{c}\text { Earth Excavation } \\
\text { Works }\end{array}$ & Stage 2 & 10 & 9 & 54 & $539,829,652$ & $66,689,064$ & $606,518,715$ \\
\hline I & $\begin{array}{c}\text { Installation of } \\
\text { kap } 8 \text { core ODP }\end{array}$ & Stage 3 & 6 & 5 & 54 & $539,829,652$ & $65,904,487$ & $605,734,138$ \\
\hline
\end{tabular}

\subsubsection{Additional 3 Hours}

Table 5 is the result of schedule compression using the TCTO method. Inactivity B or compression stage 1 , the project's duration is accelerated from 15 days to 12 days so that the total duration of the project is 52 days. This acceleration in duration resulted in an additional direct cost of Rp. 1,698,347, so the total direct cost becomes Rp. 541,095,277. The indirect cost at the compression stage 1 becomes Rp. $67,669,785$. And for the total project cost to Rp. 608,765,062. Then in activity G or compression stage 2, the project's duration is accelerated from 5 days to 4 days so that the project's total duration is 54 days. This acceleration in duration resulted in an additional direct cost of Rp. 1,698,347, so the total direct cost becomes Rp. 541,095,277.

The indirect cost for compression stage 2 becomes Rp. 65,708,342. And for the total project cost to Rp. 606,803,619. Activity $\mathrm{H}$ or compression stage 3, the project's duration is accelerated from 10 days to 8 days so that the total duration of the project is 53 days. This acceleration in duration resulted in an additional direct cost of Rp. 1,698,347, so the total direct cost becomes Rp. 541,095,277. The indirect cost for compression stage 3 becomes Rp. 66,689,064. And for the total project cost to Rp. $607,784,340$. The activity I, or the compression stage 4, the project's duration was accelerated from 6 days to 5 days so that the project's total duration was 54 days. This acceleration in duration resulted in 
an additional direct cost of Rp. 1,698,347, so the total direct cost becomes Rp. 541,095,277. The indirect cost for compression stage 4 becomes Rp. 65,904,487. And for the total project cost to Rp. $606,999,763$. Based on the calculation results, the activity with the minimum total cost value is activity G of Rp. 606,803,619.

Table 5. Additional 3 Hours

\begin{tabular}{|c|c|c|c|c|c|c|c|c|}
\hline \multirow{3}{*}{ Code } & \multirow{3}{*}{ Crash Activity } & \multirow{3}{*}{$\begin{array}{c}\text { Compression } \\
\text { stage }\end{array}$} & \multicolumn{2}{|c|}{\begin{tabular}{|l|} 
Duration \\
\end{tabular}} & \multirow{3}{*}{\begin{tabular}{|c|}
$\begin{array}{c}\text { Total } \\
\text { Duration }\end{array}$ \\
55 \\
\end{tabular}} & \multirow{3}{*}{\begin{tabular}{|c|} 
Direct Cost \\
(Rp)
\end{tabular} \mid} & \multirow{2}{*}{$\underset{(R p)}{\text { Indirect Cost }}$} & \multirow{2}{*}{$\begin{array}{c}\text { Total Cost } \\
\text { (Rp) }\end{array}$} \\
\hline & & & Normal & Crash & & & & \\
\hline & & & & & & & \begin{tabular}{|l|}
$64,727,621$ \\
\end{tabular} & $604,124,460$ \\
\hline B & $\begin{array}{l}\text { DRM and } \\
\text { licensing } \\
\text { location }\end{array}$ & Stage 1 & 15 & 12 & 52 & $541,095,277$ & $67,669,785$ & $608,765,062$ \\
\hline G & $\begin{array}{l}\text { Installation of } \\
\text { galvanized } \\
\text { pipes, HDPE } \\
\text { pipes, and } \\
\text { clamps } \\
\text { HDPE }\end{array}$ & Stage 2 & 5 & 4 & 54 & $541,095,277$ & $65,708,342$ & $606,803,619$ \\
\hline $\mathrm{H}$ & \begin{tabular}{|l} 
Earth \\
Excavation \\
Works \\
\end{tabular} & Stage 3 & 10 & 8 & 53 & $541,095,277$ & $66,689,064$ & $607,784,340$ \\
\hline I & $\begin{array}{l}\text { Installation of } \\
\text { kap } 8 \text { core } \\
\text { ODP }\end{array}$ & Stage 4 & 6 & 5 & 54 & $541,095,277$ & $65,904,487$ & $606,999,763$ \\
\hline
\end{tabular}

\subsubsection{Alternative Additional Workers}

Table 6 is the result of schedule compression using the TCTO method. In the activity I or compression stage 1, the project's duration was accelerated from 6 days to 4 days so that the project's total duration was 53 days. This acceleration in duration resulted in an additional direct cost of Rp. 50,000, so the total direct costs will be IDR 539,446,839. The indirect cost at the compression stage 1 becomes Rp. $65,904,487$. And for the total project cost to Rp. $605,351,326$. Then in activity $\mathrm{G}$ or compression stage 2 , the project's duration is accelerated, from 5 days to 3 days, so that the project's total duration is 53 days. This acceleration in duration resulted in an additional direct cost of $\mathrm{Rp}$. 58,333,333, so the total direct costs will be Rp. 539,455,172. The indirect cost for compression stage 2 becomes Rp. $65,708,342$. And for the total project cost to Rp. 605,163515.

In activity $\mathrm{J}$ or compression stage 3 , the project's duration is accelerated from 2 days to 1 day so that the total duration of the project is 54 days. This acceleration in duration resulted in an additional direct cost of Rp. 50,000, so the total direct costs will be Rp. 539,446,839. The indirect cost for compression stage 3 becomes Rp. 65,119,909. And for the total project cost to Rp. $604,556,748$. In activity $\mathrm{K}$ or compression stage 4, the project's duration is accelerated from 2 days to 1 day so that the total duration of the project is 54 days. This acceleration in duration resulted in an additional direct cost of Rp. 50,000, so the total direct costs will be Rp. 539,446,839. The indirect cost for compression stage 4 becomes Rp. $65,119,909$. And for the total project cost to Rp. 604,556,748. In activity L or compression stage 5, the project's duration is accelerated from 2 days to 1 day so that the total duration of the project is 54 days. This acceleration in duration resulted in an additional direct cost of Rp. 50,000, so the total direct costs will be Rp. 539,446,839. The indirect cost at the compression stage 5 becomes Rp. 65,119,909. And for the total project cost to Rp. 604,556,748. And for activity $\mathrm{H}$ or compression stage 6 , the duration 
of work is accelerating from 10 days to 8 days so that the project's total duration is 53 days. This acceleration in duration resulted in an additional direct cost of $\mathrm{Rp} .133,333$, so that the total direct cost is Rp. 539,530,172. The indirect cost at the compression stage 6 becomes Rp. 66,689,064. And for the total project cost to Rp. 606,219,236.

Based on the calculation results, the activity with the minimum total cost value is activity $\mathrm{J}$, activity $\mathrm{K}$, and activity $\mathrm{L}$, or at compression stages 3,4 , and 5 are Rp. 604,556,748. Because the three activities have the same total project value, the minimum cost is chosen for the activity carried out the earliest, namely activity $\mathrm{J}$ in the compression stage 3 .

Table 6. Alternative Additional Workers

\begin{tabular}{|c|c|c|c|c|c|c|c|c|}
\hline Code & Crash Activity & \multirow{2}{*}{$\begin{array}{c}\text { Compression } \\
\text { stage }\end{array}$} & \multicolumn{2}{|c|}{ Duration } & $\begin{array}{c}\text { Total } \\
\text { Duration }\end{array}$ & $\begin{array}{c}\text { Direct Cost } \\
\text { (Rp) }\end{array}$ & $\begin{array}{c}\text { Indirect Cost } \\
\text { (Rp) }\end{array}$ & $\begin{array}{c}\text { Total Cost } \\
\text { (Rp) }\end{array}$ \\
\hline & Normal & Crash & & 55 & $539,396,839$ & $64,727,621$ & $604,124,460$ \\
\hline I & $\begin{array}{l}\text { Installation of } \\
\text { kap 8 core odp }\end{array}$ & Stage 1 & 6 & 4 & 53 & $539,446,839$ & $65,904,487$ & $605,351,326$ \\
\hline G & $\begin{array}{l}\text { Installation of } \\
\text { galvanized pipes, } \\
\text { DHPE pipes and } \\
\text { HDPE clamps }\end{array}$ & Stage 2 & 5 & 3 & 53 & $539,455,172$ & $65,708,342$ & $605,163,515$ \\
\hline J & $\begin{array}{l}\text { Installation of 12 } \\
\text { core single mode } \\
\text { fiber optic duct } \\
\text { cable }\end{array}$ & Stage 3 & 2 & 1 & 54 & $539,446,839$ & $65,119,909$ & $604,566,748$ \\
\hline K & $\begin{array}{l}12 \text { core single } \\
\text { mode optical } \\
\text { cable connection }\end{array}$ & Stage 4 & 2 & 1 & 54 & $539,446,839$ & $65,119,909$ & $604,566,748$ \\
\hline L & $\begin{array}{l}1: 8 \text { passive } \\
\text { splitter } \\
\text { installation }\end{array}$ & Stage 5 & 2 & 1 & 54 & $539,446,839$ & $65,119,909$ & $604,566,748$ \\
\hline H & $\begin{array}{l}\text { Earth excavation } \\
\text { works }\end{array}$ & Stage 6 & 10 & 8 & 53 & $539,530,172$ & $66,689,064$ & $606,219,236$ \\
\hline
\end{tabular}

\section{Conclusion}

Based on the results of data collection and processing in research conducted on the STTF project batch two Indra Prahasta II housing location, the following conclusions were obtained are after performing the crashing calculations and TCTO analysis with the alternative of accelerating the addition of 1 hour, 2 hours, and 3 hours overtime work hours. The optimal total cost for an additional 1 hour of overtime work is in compression stage 2 or activity $\mathrm{H}$ with total cost is $\mathrm{Rp} 606,213,215$ and a total project duration of 54 days. For an additional 2 hours of overtime, the optimum total cost is at compression stage 3 or activity $G$ with Rp's total cost. $605,734,138$, and the total duration of the project is 54 days. The optimum total cost of adding 3 hours of overtime the optimum total cost at compression stage 3 or activity $\mathrm{J}$ with a total cost is $\mathrm{Rp}$. $606,803,619$ and a total project duration of 54 days. And for the alternative acceleration with the addition of total labor, the optimum total cost is at compression stage 3 or activity $\mathrm{J}$ with a total cost is Rp. $604,556,748$ with a total project duration of 54 days. 


\section{References}

Armalisa, A., Triana, D., Studi, P., Sipil, T., Teknik, F., Raya, U. S., Sakit, R., Daerah, U., \& Serangbanten, K. (2011). Metode Crashing Terhadap Penambahan Jam Kerja Optimum Pada Proyek Konstruksi. 1-18.

Kusumadarma, I. A., Pratami, D., Yasa, I. P., \& Tripiawan, W. (2020). Developing project schedule in telecommunication projects using critical path method (CPM). International Journal of Integrated Engineering, 12(3), 60-67. https://doi.org/10.30880/ijie.2020.12.03.008.

Nicholas, J. M. (2012). Project Management for Engineering, Business, and Technology. Project Management for Engineering, Business, and Technology. https://doi.org/10.4324/9780080967059.

Nur Hasyyati, S., Arum Puspita, I., \& Tripiawan, W. (2020). Project Acceleration of Outside Plant-Fiber Optic (OSP-FO) Project in PT. XYZ Using Time Cost Trade Off (TCTO) Method by Adding Overtime Hours. IOP Conference Series: Materials Science and Engineering, 852, 012103. https://doi.org/10.1088/1757-899x/852/1/012103

Project Management Institute. (2017). A Guide to The Project Management Body Of Knowledge (PMBOK Guide) (Six Editio).

Pratami, D., Fadlillah, F., Haryono, I., \& Bermano, A. (2018). Designing Risk Qualitative Assessment on Fiber Optic Instalation Project in Indonesia. International Journal of Innovation in Enterprise System, 2(02), 44-56. https://doi.org/https://doi.org/10.25124/ijies.v2i02.25

Pratami, Devi, Puspita, Ika Arum, and Sjafrizal, Teddy (2018). Designing internal audit process on an infrastructure project in Indonesia. Designing Internal Audit Process on Infrastructure Project in Indonesia Based on PMBOK 5th Edition, Bandung, Indonesia, 26 October 2016. Olney, Bucks, United Kingdom: Inderscience Enterprises. https://doi.org/10.1504/IJBG.2018.094098.

Setiawan, B. B., Teknik, J., Universitas, S., Jakarta, M., Jurusan, D., Sipil, T., \& Muhammadiyah, U. (2012). Analisis Pertukaran Waktu Dan Biaya Dengan Metode Time Cost Trade Off (TCTO) Pada Proyek Pembangunan Gedung di Jakarta. Jurnal Konstruksia, 4(1), 25-34. 